\title{
Quality of life of women with lymphedema after surgery for breast cancer
}

\author{
Qualidade de vida de mulheres com linfedema após cirurgia por câncer de mama \\ Calidad de vida de mujeres con linfedema después de cirugía por cáncer de mama
}

Marislei Sanches Panobianco ${ }^{1}$, Natalia Campacci ${ }^{1}$, Letícia Meda Vendrusculo Fangel ${ }^{2}$, Maria Antonieta Spinoso Prado $^{1}$, Ana Maria de Almeida ${ }^{1}$, Thais de Oliveira Gozzo ${ }^{1}$

This study evaluated the quality of life of 20 women with post-mastectomy lymphedema due to breast cancer, using the Flanagan's Adapted Quality of Life Scale (1) and the Visual Analogue Scale (2), with data collection from July to December 2009 in the countryside of the state of São Paulo, Brazil. It was observed a lower quality of life concerning participation in recreational and work activities, and better quality of life was related to relationship with friends; listening to music, reading, watching TV and going to the movies. Cronbach's alpha of Scale 1 was 0.86 and the average of Scale 2 was 6.26. Overall, the scales showed satisfactory results of quality of life, but low values showed factors that must be worked out, such as participation in sports, work and learning activities. Thus, lymphedema interferes with the quality of life, indicating a need for early intervention in order to help women achieve better quality of life.

Descriptors: Breast Neoplasms; Lymphedema; Quality of Life; Women.

Estudo avaliou a qualidade de vida de 20 mulheres com linfedema pós-mastectomia por câncer de mama, com uso da Escala de Qualidade de Vida de Flanagan adaptada (1) e Escala Visual Analógica (2), com coleta de dados de julho a dezembro de 2009, no interior do estado de São Paulo, Brasil. Observou-se menor qualidade de vida quanto participação em atividades de recreação e trabalho, melhor qualidade de vida foram relacionamento com amigos; ouvir música, ler, assistir à TV, ir ao cinema. 0 alfa de Cronbach da Escala 1 foi 0,86 e Média da Escala 2 foi 6,26. Globalmente, as Escalas mostraram resultados de qualidade de vida satisfatória, porém baixos valores evidenciam fatores que devem ser trabalhados, como a participação em atividades esportivas, trabalho e aprendizado. Assim, o linfedema interfere na qualidade de vida, indicando necessidade de intervenções precoces, no sentido de auxiliar as mulheres a alcançar melhor qualidade de vida.

Descritores: Neoplasias da Mama; Linfedema; Qualidade de Vida; Mulheres.

Estudio evaluó la calidad de vida de 20 mujeres con linfedema post mastectomía por cáncer mamario, con uso de la Escalas de Calidad de Vida de Flanagan adaptada (1) y Escala Visual Analógica (2), con recopilación de datos de julio a diciembre de 2009, en interior del São Paulo, Brasil. Se observó menor calidad de vida en la participación en actividades de ocio y trabajo; mejor calidad de vida fueron: relación con amigos, escuchar música, leer, ver TV e ir al cine. 0 alfa de Cronbach para Escala 1 fue 0,86 y para Escala 2, 6,26. Las escalas señalaron, globalmente, resultados satisfactorios de calidad de vida, pero, bajos valores comprueban existencia de factores que deben ser discutidos, como la participación en recreación, actividades deportivas, trabajo y aprendizaje. El linfedema interfiere en la calidad de vida, indicando necesidad de intervenciones tempranas para ayudar las mujeres a lograr mejor calidad de vida.

Descriptores: Neoplasias de la Mama; Linfedema; Calidad de Vida; Mujeres.

\footnotetext{
${ }^{1}$ Escola de Enfermagem de Ribeirão Preto, Universidade de São Paulo. Ribeirão Preto, SP, Brazil.

${ }^{2}$ Universidade de Brasília. Brasília, DF, Brazil. 


\section{Introduction}

Worldwide, approximately 140 million people are living with lymphedema, 20 million as a result of postoperative breast cancer representing $98 \%$ of cases of upper limb edema ${ }^{(1)}$.

Lymphedema is a chronic, progressive, hard to deal with and generally incurable disease, common in the postoperative period of surgery and radiotherapy for cancer treatments ${ }^{(2)}$. For breast cancer, lymphedema is the postoperative complication of major morbidity, and affects directly women's quality of life $e^{(3)}$.

Post-mastectomy lymphedema causes a severe esthetic and functional damage to the affected limb, harming the social activities of affected women. It still represents a great physical and emotional discomfort by causing symptoms of depression and anxiety, as well as memories of the cancer itself, often requiring psychological and psychiatric monitoring ${ }^{(4)}$.

The comparison between the results of studies about the prevalence or incidence of lymphedema after surgery for breast cancer is difficult due to differences in the methods used in the classification and cutoff used for diagnosis of lymphedema, in the followup time and in the characteristics of the population studied $^{(5)}$. Given this variation in diagnostic methods available, it is not surprising that the incidence of lymphedema secondary to mastectomy varies widely, with values from $6 \%$ to $80 \%{ }^{(6)}$.

Treatment can be long, bring about changes in lifestyle, and consequently deficits in quality of life, since there is a significant change in women's routine. Among them there are changes in clothing style, difficulty performing everyday tasks and discomfort in sexual life, which leads to loss of interest in social and personal activities ${ }^{(7-8)}$.

The measure of quality of life may be useful to monitor the reduction in functional capacity and identify physical and emotional problems; as a facilitator in the communication between doctor and patient; to monitor the response to treatment or disease progression, patient's education, among others $^{(9-10)}$.

Acting in the rehabilitation of women with breast cancer, one observed difficulties and limitations in movement of the upper limb with lymphedema, its impact on women's lives, and especially the negative consequences that it might bring. One asks how lymphedema interferes in these women's every day life and how it affects their quality of life. Thus, this study aimed to evaluate the quality of life of women with post-mastectomy lymphedema due to breast cancer, followed by a rehabilitation service, applying two different scales.

\section{Method}

This is a cross-sectional, descriptive study with a quantitative analysis, developed in a rehabilitation service for mastectomized women in the state of São Paulo in the period from July to December 2009. This service aims atcomprehensive care in the rehabilitation of women with breast cancer, contemplating their physical, emotional and psychosocial rehabilitation by a multidisciplinary team (nurses, psychologists, physiotherapists, occupational therapists and nutritionists), who work across disciplines, offering discussion groups or individual therapy sessions, group exercises, prevention, control and treatment for lymphedema and other post-operative complications, leisure and recreational activities, among others.

A convenience sampling was performed and one used as inclusion criteria: being enrolled in the service; present, concerning perimeter, a circumference difference between the upper limbs equal to or greater than three centimeters, at any of the point assessed during the collection period; not having active diseases at the time of data collection and having conditions to understand and answer questions.

From a survey on hospital and perimeter control records, one attempted to select women with lymphedema bigger than or equal to $3 \mathrm{~cm}$. Those with 
active disease were excluded.

The invitation to the selected ones to participate in the research was conducted in days and hours of service to assiduous women in the second half of 2009. For women who were enrolled in the service, but who were not going there during data collection, contact by phone was performed previously. Those who agreed to participate were scheduled to meet at home for the conduction of the interview.

Considering the inclusion criteria of the study, 25 women met these criteria. Among them, four refused to participate and one had died. Thus, 20 women participated.

The participants' socioeconomic and perimetry data were collected from their medical records. For those who were not attending the service, perimetry was performed at home with the aim of confirming if they kept the difference equal to or bigger than $3 \mathrm{~cm}$ between the upper limbs, which was confirmed for all of them.

For this study one used perimetry, measurement used for mensuration of the upper limbs' circumference. To classify lymphedema, it was considered the difference between members and when it was less than three $\mathrm{cm}$, it was considered mild lymphedema, three to five $\mathrm{cm}$ moderate, and severe, above five $\mathrm{cm}^{(11)}$.

For the assessment of Quality of Life two instruments were applied: Visual Analogue Scale ${ }^{(12)}$ and the Flanagan's Adapted Quality of Life Scale ${ }^{(13)}$, translated into more than 16 languages, including Portuguese, in Brazil. In this version, all items are in Likert scale of seven points, as well as in the original scale, the potential score ranged from 15 to 105 points ${ }^{(12)}$. The questions of the scale include aspects about physical and mental well-being, personal relationships and involvement in social and leisure activities, development and personal enrichment. The modified version contains 16 items, with the additional item "independence"(13).

The use of the Visual Analogue Scale was intended to complement Flanagan's Adapted Scale of Quality of Life, since it can be used to measure the intensity, strength or magnitude of individual sensations, subjective feelings or the magnitude of individual relationships. The utility measures to assess quality of life consider the Visual Analogue Scale as a measure of direct assessment that questions individuals directly on their preferences ${ }^{(12)}$.

The Visual Analogue Scale consists of a $10 \mathrm{~cm}$ line, where zero is the worst quality of life possible and 10 the best quality of life possible that interviewees could imagine. In this study, from the question: "How would you rate your quality of life since you developed lymphedema in your arm?", participants were asked to mark on the line from zero (poor quality of life) to 10 (great quality of life), where their quality of life fit since the onset of lymphedema in their arms.

To answer Flanagan's Adapted Quality of Life Scale, the interviewees were asked to relate the questions and answers with the presence of lymphedema on their arms.

For the data analysis of Flanagan's Adapted Quality of Life Scale, they were grouped in Excel 2007, and one used the Statistic 7.0 software for statistical analysis. To assess the internal consistency of Flanagan's Adapted Quality of Life Scale, one calculated Cronbach's alpha, which in order to prove the reliability of the applied scale should be between 0.7 and $1.0^{(14)}$.

The data obtained through responses of the Visual Analogue Scale were analyzed by measuring the zero point until the point marked by the client, and evaluated through the average and standard deviation of the measures found.

To compare the results, the data regarding the Visual Analogue Scale and the Flanagan's Scale of Quality of Life in its adapted version ${ }^{(12)}$, were placed in the same pattern.

This study was approved by the Ethics Committee in Research of the Escola de Enfermagem de Ribeirão Preto [Ribeirão Preto Nursing School], from the Universidade de São Paulo [University of São Paulo] (protocol number 1031/2009). 


\section{Results}

The average age of the 20 participants was 65.5 years old, ranging from 40 to 82 years old. Regarding education, $45 \%$ had incomplete elementary education, and also, 45\% were married and 40\% were housewives. The average time of surgery, at the time of data collection was 12.3 years, while about the time of women's involvement in the rehabilitation service, it was found that $5 \%$ had been attending it for 21 years; $20 \%$ for 14 years; $20 \%$ for nine years and $55 \%$ for four years (Table 1).

Table 1 - Distribution of women according to age, marital status, education and occupation $(n=20)$

\begin{tabular}{lc}
\hline Variables & n (\%) \\
\hline Age (years) & \\
$40-49$ & $2(10.0)$ \\
$50-59$ & $4(20.0)$ \\
$60-69$ & $6(30.0)$ \\
$\geq 70$ & $8(40.0)$ \\
Marital status & \\
Single & $4(20.0)$ \\
Married & $9(45.0)$ \\
Separated & $3(15.0)$ \\
Widow & $4(20.0)$ \\
Education & \\
Incomplete Elementary Educ. & $9(45.0)$ \\
Complete Elementary Educ. & $5(25.0)$ \\
Complete High School & $4(20.0)$ \\
Complete Higher Educ. & $2(10.0)$ \\
Occupation & \\
Retired & $2(20.0)$ \\
Housewife & $9(45.0)$ \\
Salesperson & $1(5.0)$ \\
Other & $6(30.0)$ \\
\hline
\end{tabular}

On the day of data collection, the values of upper limb's perimetry showed that $25 \%$ had measures with a difference of three $\mathrm{cm}$, in $50 \%$ the difference varied between three and five centimeters and $25 \%$ had measures bigger than five centimeters.

Flanagan's Adapted Quality of Life Scale showed higher values in relation to a greater satisfaction of individuals. In this study, the responses' interval ranged from 49 to 98 , with an average of 76.7 and standard deviation of 15.6 .

The items corresponding to a smaller satisfaction of participants, ie, those whose achievement was compromised by the arm lymphedema were: participating in sports recreational activities; working on their job or at home; learning: being able to increase their general knowledge.

The items with better satisfaction, in which the upper limb lymphedema did not affect their routine of performance were: relationships with friends; listening to music, reading, watching television and going to the movies, and other items such as: getting to communicate, meeting people and doing things together and helping others (Table 2).

Table 2 - Descriptive statistics of the participants' responses to items from Flanagan's Quality of Life Scale in its adapted version $(n=20)$

\begin{tabular}{|c|c|c|c|}
\hline Scale items & $\begin{array}{c}\text { Avera- } \\
\text { ge }\end{array}$ & $\begin{array}{c}\text { Standard } \\
\text { Deviation }\end{array}$ & $\begin{array}{c}\text { Media- } \\
\text { na }\end{array}$ \\
\hline $\begin{array}{l}\text { Q1 - Material Comfort: housing, } \\
\text { food and financial situation }\end{array}$ & 4.2 & 1.7 & 6 \\
\hline $\begin{array}{l}\text { Q2 - Health: feel physically well } \\
\text { and full of energy }\end{array}$ & 4.4 & 2.1 & 6 \\
\hline $\begin{array}{l}\text { Q3 - Relationships with parents, } \\
\text { siblings and other relatives: live } \\
\text { together and help }\end{array}$ & 5.3 & 1.5 & 6 \\
\hline Q4 - Have and raise children & 5.0 & 1.3 & 4 \\
\hline $\begin{array}{l}\text { Q5 - Relationship with spouse or } \\
\text { partner }\end{array}$ & 4.5 & 1.7 & 4 \\
\hline Q6 - Relationship with friends & 5.8 & 1.4 & 6 \\
\hline $\begin{array}{l}\text { Q7 - Help and support other } \\
\text { people }\end{array}$ & 5.6 & 1.9 & 6 \\
\hline $\begin{array}{l}\text { Q8 - Participation in community } \\
\text { associations and public interest } \\
\text { activities }\end{array}$ & 4.8 & 1.8 & 6 \\
\hline $\begin{array}{l}\text { Q9 - Learning: be able to increase } \\
\text { their general knowledge }\end{array}$ & 4.0 & 2.1 & 6 \\
\hline $\begin{array}{l}\text { Q10 - Self-knowledge: know about } \\
\text { their strengths and limitations, } \\
\text { know where they want to reach } \\
\text { and what important goals for } \\
\text { their lives are }\end{array}$ & 4.1 & 1.9 & 6 \\
\hline $\begin{array}{l}\text { Q11 - Work on their jobs or at } \\
\text { home }\end{array}$ & 3.8 & 2.1 & 6 \\
\hline Q12 - Be able to communicate & 5.6 & 1.3 & 6 \\
\hline $\begin{array}{l}\text { Q13 - Participate in sports } \\
\text { recreational activities }\end{array}$ & 3.7 & 1.2 & 4 \\
\hline $\begin{array}{l}\text { Q14 - Listen to music, read, watch } \\
\text { TV and go to the movies }\end{array}$ & 5.7 & 1.3 & 6 \\
\hline $\begin{array}{l}\text { Q15 - Meet other people and do } \\
\text { things together }\end{array}$ & 5.6 & 1.5 & 6 \\
\hline $\begin{array}{l}\text { Q16 - Independence: feel able to } \\
\text { do things for themselves }\end{array}$ & 4.9 & 2.2 & 6 \\
\hline $\begin{array}{l}\text { Total value of Flanagan's Quality } \\
\text { of Life Scale }\end{array}$ & 76.7 & 15.6 & 78 \\
\hline
\end{tabular}


To assess the internal consistency of Flanagan's Adapted Quality of Life Scale, it was calculated Cronbach's alpha, with a result of 0.86 , which proves the reliability of the scale applied, since it is bigger when the Cronbach coefficient is between 0.7 and $1.0^{(14)}$.

For the Visual Analogue Scale, the average obtained from the results of this scale was 6.26, which can represent quality of life with a positive satisfaction, despite the appearance of arm lymphedema.

Data related to the Visual Analogue Scale and Flanagan's Quality of Life Scale ${ }^{(13)}$, in its adapted version, were placed in the same pattern, as shown in Table 3.

Table 3 - Relationship between results of the participants' responses to the Visual Analogue Scale and Flanagan's Quality of Life Scale adapted version and their respective standardization $(\mathrm{n}=20)$

\begin{tabular}{lcc}
\hline Client number & $\begin{array}{c}\text { VAS* } \\
\text { Total (\%) }\end{array}$ & $\begin{array}{c}\text { Flanagan } \\
\text { Total (\%) }\end{array}$ \\
\hline 1 & $8.9(89.0)$ & $98(87.5)$ \\
2 & $9.2(92.0)$ & $94(83.9)$ \\
3 & $8.0(80.0)$ & $79(70.5)$ \\
4 & $5.8(58.0)$ & $81(72.3)$ \\
5 & $6.3(63.0)$ & $93(83.0)$ \\
6 & $6.8(68.0)$ & $78(69.6)$ \\
7 & $4.4(44.0)$ & $49(43.8)$ \\
8 & $5.6(56.0)$ & $62(55.4)$ \\
9 & $7.5(75.0)$ & $85(75.9)$ \\
10 & $7.2(72.0)$ & $88(78.6)$ \\
11 & $8.9(89.0)$ & $84(75.0)$ \\
12 & $3.5(35.0)$ & $49(43.8)$ \\
13 & $2.9(29.0)$ & $55(49.1)$ \\
14 & $6.0(60.0)$ & $83(74.1)$ \\
15 & $4.5(45.0)$ & $78(69.6)$ \\
16 & $8.9(89.0)$ & $88(78.6)$ \\
17 & $7.1(71.0)$ & $89(79.5)$ \\
18 & $7.0(70.0)$ & $55(49.1)$ \\
19 & $5.5(55.0)$ & $61(54.5)$ \\
20 & $4.0(40.0)$ & $85(75.9)$ \\
\hline VAS- Visual Analogue Scale & &
\end{tabular}

During data analysis, one compared the values obtained about the participants' responses out of the research tools and the time of participation in the rehabilitation unit, as it can be analyzed in Table 4 .
Table 4 - Relationship between time of participation in the rehabilitation service with the result of the participants' responses to the Visual Analogue Scale and Flanagan's Quality of Life Scale adapted version, of each participant client $(n=20)$

\begin{tabular}{lccc}
\hline $\begin{array}{l}\text { Client } \\
\text { number }\end{array}$ & $\begin{array}{c}\text { Time in service } \\
\text { (years) }\end{array}$ & $\begin{array}{c}\text { VAS* } \\
\text { Total (\%) }\end{array}$ & $\begin{array}{c}\text { Flanagan } \\
\text { Total (\%) }\end{array}$ \\
\hline 1 & 0.2 & $8.9(89.0)$ & $98(87.5)$ \\
2 & 1 & $9.2(92.0)$ & $94(83.9)$ \\
9 & 1 & $7.5(75.0)$ & $85(75.9)$ \\
18 & 1 & $7.0(70.0)$ & $55(49.1)$ \\
19 & 1 & $5.5(55.0)$ & $61(54.5)$ \\
20 & 1 & $4.0(40.0)$ & $85(75.9)$ \\
6 & 2 & $6.8(68.0)$ & $78(69.6)$ \\
13 & 3 & $2.9(29.0)$ & $55(49.1)$ \\
3 & 4 & $8.0(80.0)$ & $79(70.5)$ \\
11 & 4 & $8.9(89.0)$ & $84(75.0)$ \\
16 & 4 & $8.9(89.0)$ & $88(78.6)$ \\
10 & 7 & $7.2(72.0)$ & $88(78.6)$ \\
14 & 7 & $6.0(60.0)$ & $83(74.1)$ \\
15 & 7 & $4.5(45.0)$ & $78(69.6)$ \\
4 & 8 & $5.8(58.0)$ & $81(72.3)$ \\
8 & 10 & $5.6(56.0)$ & $62(55.4)$ \\
12 & 11 & $3.5(35.0)$ & $49(43.8)$ \\
7 & 16 & $4.4(44.0)$ & $49(43.8)$ \\
17 & 18 & $7.1(71.0)$ & $89(79.5)$ \\
5 & 21 & $6.3(63.0$ & $93(83.0)$ \\
\hline VAS - Visual Analogue Scale & &
\end{tabular}

\section{Discussion}

The two instruments applied during data collection reveal similarities in their results, regarding the quality of life of the people studied. Authors claim that people with lymphedema on the upper limb have low quality of life, but there is no consensus about its impact in the areas assessed ${ }^{(15)}$.

The literature shows that, despite the various treatment modalities for breast cancer, women who have undergone them can have negative effects on their lives, such as deficits in emotional, cognitive and social functions. Furthermore, these effects can persist for long periods, however the quality of life after three years of treatment, is similar to the population in general $^{(16)}$.

Women with breast cancer who presented signs and symptoms of fatigue and depression showed impairment in their quality of life, being the lowest scores related to sexual satisfaction, sexual 
performance and future prospects. Moreover, the results indicated that the symptoms of breast and arm hindered their body image ${ }^{(17)}$. In this sense, the authors recommend that these factors should be better worked in the process of rehabilitation of women with breast cancer.

Concerning the implementation of Flanagan's Adapted Quality of Life Scale, the results of this study showed a high value, what corresponds to a better quality of life. However, scholars of this subject ${ }^{(18-19)}$ point out the importance of paying attention to the other items of the scale, which in this study did not harm quality of life very much, but revealed aspects that are still not satisfactory, and if these factors are not remedied or mitigated, they can seriously compromise quality of life over time.

It can be observed that the items "learning" (being able to increase their general knowledge) and "work on their job or at home" showed poor results, showing that the arm's increased measurement interfered, compromising their quality of life at work. This increased measurement generates limitations of fine movements of the upper limb, a fact that causes difficulty in performing daily and pleasurable activities, requiring reorganization of these activities, including domestic tasks ${ }^{(19)}$.

Corroborating these results, it can be observed that the presence of lymphedema interferes directly in daily activities, besides the fact that quality of life encompasses many aspects such as functional ability and satisfaction with daily activities ${ }^{(20)}$.

Therefore, by analyzing the characteristics of women regarding the upper limb's perimeter, it was observed that $50 \%$ of them have measurements from three to five centimeters, lymphedema rated as moderate. This, if not adequately dealt with, can progress and cause complications such as limitations and decreased range of movements ${ }^{(21)}$. However, physical rehabilitation is favorable to the improvement of these symptoms, as demonstrated with the assessment of the practice of global physical exercises which improved the physical function, general health and vitality of women with lymphedema ${ }^{(22)}$. Clarification and guidance on the maintenance of movement of the upper limb can improve or help maintain quality of life ${ }^{(19)}$.

As for the items that demonstrate better quality of life, "relationships with friends", "listening to music, reading, watching TV and going to the movies" and the items "getting to communicate", "meeting people and doing things together" and "helping other people", it is noticed that they are actions that are related to social interaction. In contrast to this finding, it was observed that women with lymphedema have difficulties related to the acceptance of their body image, and then, with social relationships ${ }^{(19)}$.

One factor that may affect positively the quality of life of women with breast cancer is their participation in rehabilitation centers $^{(22)}$. In this sense, it is noteworthy that women with lymphedema, described that they identified the rehabilitation service as a place that offers support, care and information about the disease ${ }^{(19)}$.

As well as in Flanagan's Adapted Quality of Life Scale, the application of the Visual Analogue Scale showed satisfactory results of quality of life, when analyzed globally. However, it is important to highlight the existence of low scores in both scales, demonstrating women's dissatisfaction, and proving the existence of factors that should be better addressed by health workers who care for them, such as participating in sports recreational activities; working on their jobs or at home; learning: being able to increase their general knowledge.

It is essential to analyze the domains of quality of life affected by the presence of lymphedema and plan interventions for these patients' rehabilitation ${ }^{(8)}$.

\section{Conclusion}

Both Flanagan's Adapted Quality of Life Scale and the Visual Analogue Scale showed satisfactory results of quality of life, when analyzed as a whole, but some items of the first scale are still not satisfactory, 
such as "learning" (being able to increase their general knowledge); "Working in their jobs or at home"; sexual performance and satisfaction; future prospects.

In spite of the small sample, the findings reinforce the need to implement new studies assessing the quality of life of women with lymphedema due to breast cancer. Health professionals, especially Nursing ones, which attend these patients must be aware to guide and act appropriately about lymphedema's prevention and control, a postoperative complication that can compromise seriously the quality of life of the women affected.

\section{Acknowledgments}

To the Conselho Nacional de Desenvolvimento Científico e Tecnológico [National Council of Scientific and Technological Development] for the financial support (Process No. 2007/50627-9).

\section{Collaborations}

Panobianco MS, Campacci N, FangelVendrusculo LM and Prado MAS contributed to the creation, field data collection, analysis, data interpretation, writing of the article and final approval of the version to be published. Almeida AM and Gozzo TO contributed to the analysis, data interpretation, writing of the article and final approval of the version to be published.

\section{References}

1. Santos DA, Cipolla LV, Oliveira MMF. Atuação da fisioterapia no tratamento do linfedema após câncer de mama. Ensaio Ciênc. 2010; 14(1):17786.

2. International Society of Limphology. The diagnosis and treatment of peripheral lymphedema: 2013. Consensus document of the International Society of Lymphology. Lymphology. 2013; 46(1):1-11.
3. Fu MR, Axelrod D, Haber J. Breast-cancer-related lymphedema: information, symptoms, and risk-reduction behaviors. J Nurs Schol. 2008; 40(4):341-8.

4. Panobianco MS, Mamede MV, Almeida AM, Clapis MJ, Ferreira CB. Experiência de mulheres com linfedema pós-mastectomia: significado do sofrimento vivido. Psicol Estud. 2008; 13(4):80716.

5. Hayes SC. Review of research evidence on secondary lymphedema: incidence, prevention, risk factors and treatment [Internet]. [cited 2013 Apr 9] Sydney. National Breast and Ovarian Cancer Centre; 2008. Available from: http:// canceraustralia.gov.au/sites/default/files/ publications/slerw-review-research-secondarylymphoedema_504af03e2a20c.pdf

6. Hayes SC. Review of research evidence on secondary lymphedema: incidence, prevention, risk factors and treatment. Australia. National Breast and Ovarian Cancer Centre; 2008.

7. Ahmed RL, Prizment A, Lazovich D, Schimitz KH, Folsom AR. Lymphedema and Quality of Life in Breast Cancer Survivors: The Iowa Women's Health Study. J Clin Oncol. 2008; 26(35):5689-96.

8. Zandonai AP, Cardozo FMC, Nieto ING, Sawada NO. Qualidade de vida nos pacientes oncológicos: revisão integrativa da literatura latino-americana. Rev Eletr Enf. [periódico na Internet]. 2010 [citado 2013 abril 9]; 12(3): 554-61. Disponível em: http://www.fen.ufg.br/revista/v12/n3/ v12n3a20.htm

9. Perry S, Kowalski TL, Chang CH. Quality of life assessment in women with breast cancer: benefits, acceptability and utilization. Health Qual Life Outcomes. 2007; 5:24.

10. Donaldson M. Using patient-reported outcomes in clinical oncology practice: benefits, challenges and next steps. Expert Rev Pharmacoeconomics Outcomes Res. 2006; 6(1):87-95.

11. Shih YCT, Xu Y, Cormier JN, Giordiano S, Ridner SH, Buchholz TA, et al. Incidence, treatment costs, and complications of lymphedema after breast cancer among women of working age: a 2-year follow-up study. J Clin Oncol. 2009; 27(12):2007-14.

12. Monteiro R, Braile DM, Brandau R, Jatene FB. 
Qualidade de vida em foco. Rev Bras Cir Cardiovasc. 2010; 25(4):568-74.

13. Corrente JE, Machado ABC. Avaliação da qualidade de vida da população idosa numa estância turística do interior do estado de São Paulo: Aplicação da escala de Flanagan. Rev APS. 2010; 13(2):156-63.

14. Cronbach LJ. Coefficient alpha and the intern structure of tests. Psychometr Soc.1951; 16(3):297-334.

15. Hormes JM, Bryan C, Lytle LA, Gross CR, Ahmed $\mathrm{RL}$, Troxel $\mathrm{AB}$, et al. Impact of lymphedema and arm symptoms on quality of life in breast cancer survivors. Lymphology. 2010; 43(1):1-13.

16. Vendrusculo-Fangel LM, Panobianco MS, Kebbe LM, Almeida AM, Gozzo TO. Qualify of life and daily activities performance after breast cancer treatment. Acta Paul Enferm. 2013; 26(1):93-100.

17. Panobianco MS, Magalhães PAP, Oliveira ISB, Gozzo TO. Depressão e fadiga na qualidade de vida de mulheres com câncer de mama. Rev Rene. 2011; 12(2):247-52.
18. Hoving JL, Broekhuizen MLA, Frings-Dresen MHW. Return to work of breast cancer survivors: a systematic review of intervention studies. BMC Cancer. 2009; 9(1):117.

19. Chachaj A, Mayszczak K, Pryszel K, Lukas J, Tarkowski R. Physical and psychological impairments of women with upper limb lymphedema fallowing breast cancer treatment. Psychol Oncol. 2010; 19(3):299-305.

20. Alegrance FC, Souza CB, Mazzei RL. Qualidade de vida e estratégias de enfrentamento em mulheres com e sem linfedema pós-câncer de mama. Rev Bras Cancerol. 2010; 56(3):341-51.

21. Pinheiro CPO, Silva RM, Mamede MV, Fernandes AFC. Participating in a support group: experience lived by women with breast cancer. Rev Latino-Am Enfermagem. 2008; 16(4):733-8.

22. Scaffidi M, Vulpiani MC, Vetrano M, Conforti F, Marchetti MR, Bonifacino A, et al. Early rehabilitation reduces the onset of complications in the upper limb following breast cancer surgery. Eur J Phys Rehabil Med. 2012; 48(4):601-11. 